\title{
STUDIES ON THE MODE OF ACTION OF IRRADIATED ERGOSTEROL
}

\author{
IV. IN HyPOPARATHYROIDISM ${ }^{1,2}$ \\ By WALTER BAUER, ALEXANDER MARBLE ${ }^{3}$ AND DOROTHY CLAFLIN \\ (From the Medical Clinic of the Massachusetts General Hospital, Boston)
}

(Received for publication June 6, 1931)

The hypothesis has been advanced that irradiated ergosterol acts only by stimulating the parathyroid glands (1-3). Yet various workers have reported beneficial results in the treatment of parathyroid deficiency with irradiated ergosterol (1), (3), (4-10). It is difficult to believe that if irradiated ergosterol acts by stimulating the parathyroid glands, its administration to completely parathyroidectomized animals should result in alleviation of the tetany and restoration of the serum calcium and phosphorus to normal values. The lack of complete calcium and phosphorus metabolism data, failure to state the dietary intake, and variations in dosage as well as differences in potency of the irradiated ergosterol preparations employed, make it difficult to draw any conclusions from the work reported in the literature as to the mode of action of irradiated ergosterol in parathyroid tetany. The results obtained in certain instances may very well have been due to overdosage of this potent vitamin $\mathrm{D}$ preparation (8).

In previous communications (11-13), data have been presented which were interpreted as signifying that irradiated ergosterol acted by increasing the absorption of calcium and phosphorus from the gastro-intestinal tract. If such an interpretation of the data is correct, then the beneficial results obtained in the treatment of parathyroid deficiency must bear a direct relation to the calcium intake. In an attempt to substantiate or disprove such a theory, calcium and phosphorus metabolism experiments were carried out on patients with parathyroid tetany, on varying calcium intakes, with and without irradiated ergosterol therapy. The phosphorus intake was kept constant throughout each experiment.

Three cases of hypoparathyroidism, two with idiopathic and one with postoperative parathyroid tetany, were studied. They all showed the characteristic features of this disease syndrome, namely: the signs and

${ }^{1}$ This is publication No. 7 of the Robert W. Lovett Memorial for the study of crippling disease, Harvard Medical School, Boston, Massachusetts.

${ }^{2}$ Part of the expense of this investigation was paid by the William W. Wellington Memorial Research Fund.

${ }^{3}$ Medical Resident, Massachusetts General Hospital. 
symptoms of tetany, low serum calcium, high serum phosphorus, and bones which appeared on x-ray examination to be of normal density. The calcium and phosphorus content of the diet given each individual was kept constant throughout each experiment. The total calcium intake was varied by administering calcium in the form of calcium chloride. One patient (Mr. B. W., experiment I) was maintained on a diet adequate in calcium, 2.08 grams per three-day period; the others received an inadequate calcium intake, 0.30 gram per three-day period. It was hoped that by this method of study it would be possible to determine whether or not the effects obtained were secondary to the calcium intake or to stimulation of remaining parathyroid tissue.

\section{METHODS}

These three patients were studied under the same conditions as those previously described (11-12). The collection and preparation of the excreta and the methods of analyses used were identical with those employed in studies I and II (11-12).

\section{Experiment I}

\section{EXPERIMENTS}

Mr. B. W., a 54-year old retired Jewish tailor, had suffered from idiopathic parathyroid tetany for five years. His data are presented in Charts $1 A, 1 B$, and Table I.

During the control periods (49-51), his dietary calcium intake was 2.08 grams per period; in addition he received $36 \mathrm{cc}$. of a 45 per cent solution of calcium chloride ${ }^{4}$ each period, his average calcium intake per period being 7.79 grams. The average total calcium excretion was 4.71 grams, 0.28 gram in the urine and 4.43 grams in the feces, the average positive balance being 3.08 grams. Beginning with period 52, he received $5 \mathrm{mgm}$. of irradiated ergosterol a day. During the first period of medication a rise in the fecal calcium and a fall in the urinary calcium occurred, unexplained phenomena which have been observed in previous studies (11). In the subsequent periods (53-57) the fecal calcium fell to such a degree that, although the urinary calcium rose, the positive calcium balance increased. The calcium intake was reduced during the next two periods (58-59) and the effect on the calcium metabolism is well shown in Table I. During periods 60-64, calcium chloride was discontinued, resulting in a further reduction of the calcium excretion and the positive calcium balance. When, however, the calcium intake was again raised to 7.90 grams by the administration of calcium chloride (periods 65-66), there resulted a positive calcium balance greater than that in periods 5257 , when the intake and the ergosterol dosage were the same. The urinary calcium was higher, the fecal calcium lower.

${ }^{4}$ The calcium chloride solution employed contained $162 \mathrm{mgm}$. of calcium per cc. of solution. 


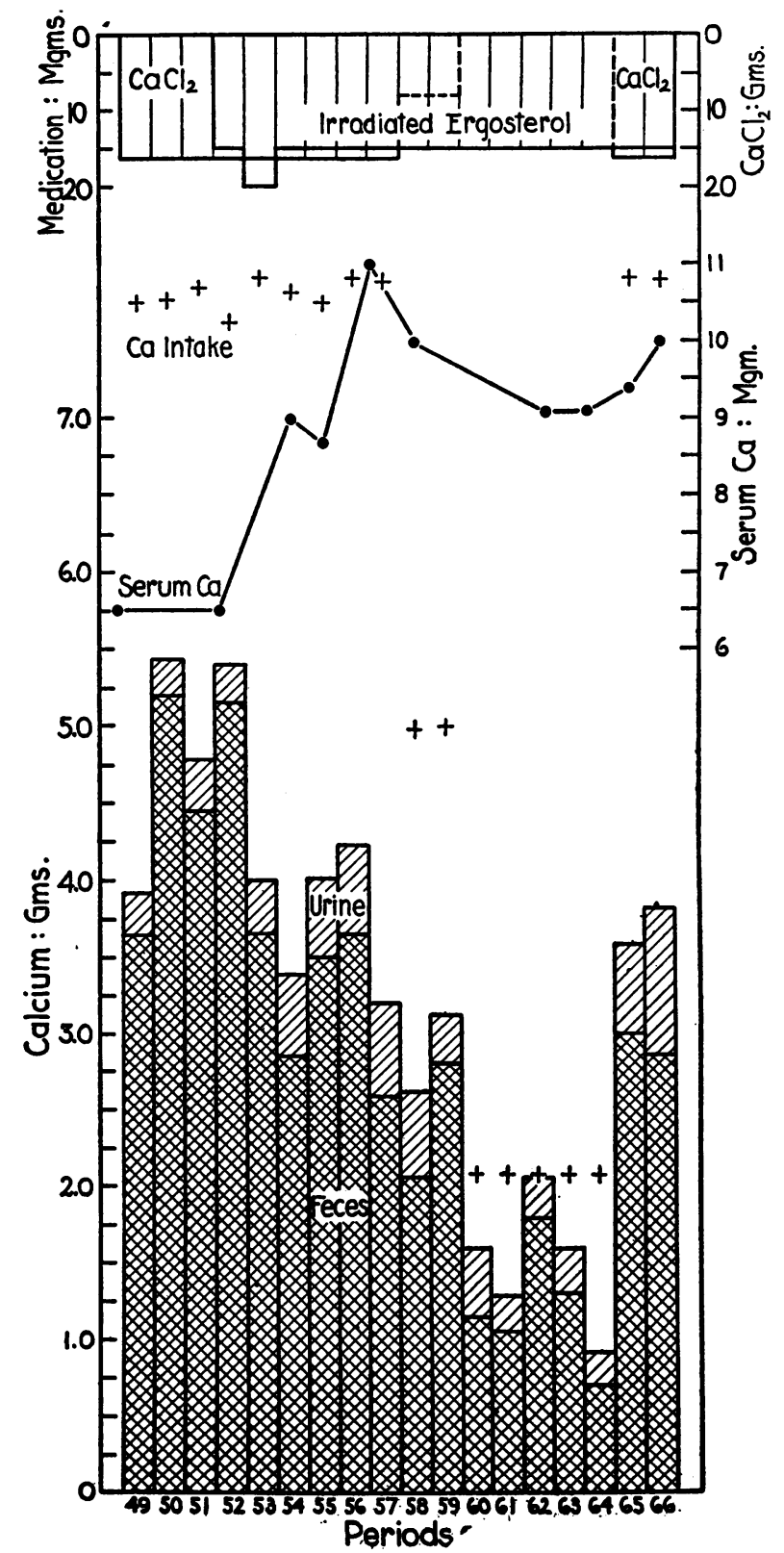

Chart 1 $A$. Calcium Metabolism in Experiment I 
The changes in the phosphorus metabolism following the administration of irradiated ergosterol were a gradual increase in both the urinary and fecal values and consequently a decrease in the phosphorus balance. See Table I. These changes will be discussed in more detail below.

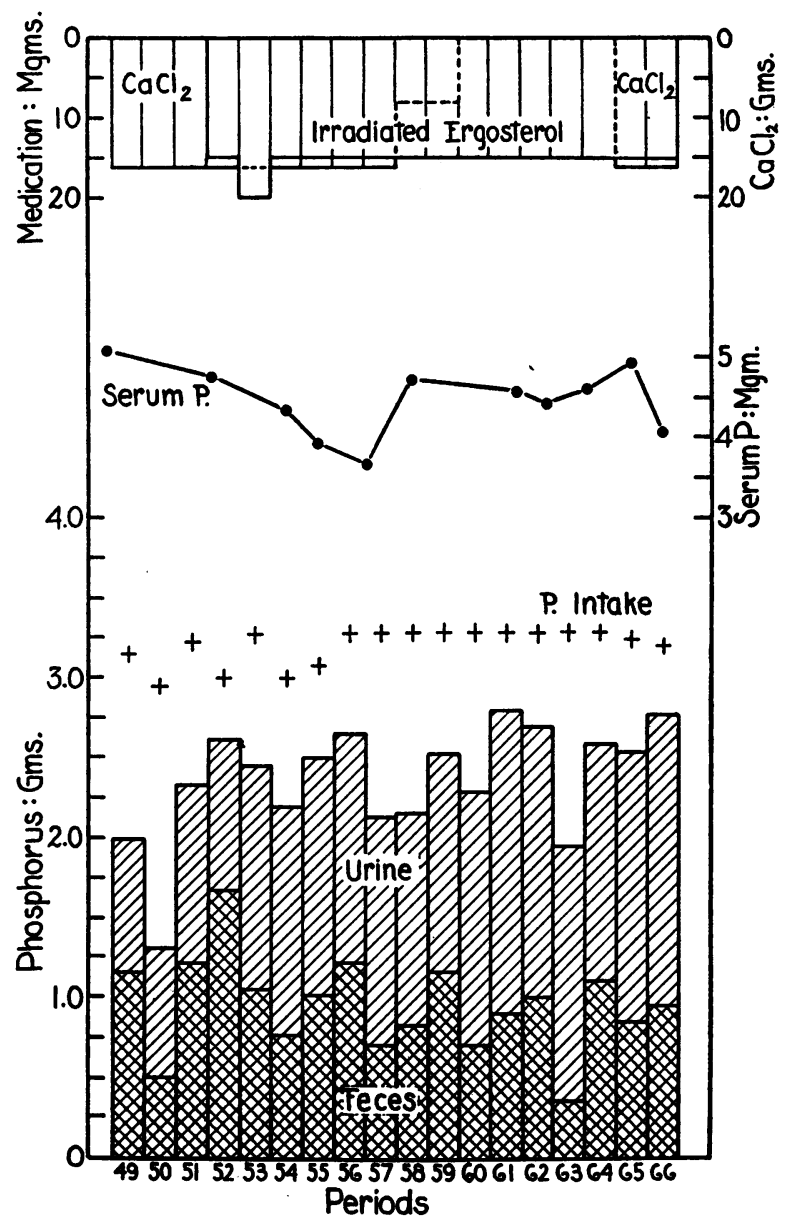

Chart $1 B$. Phosphorus Metabolism in Experiment I

The most interesting and significant changes noted in this experiment were those of the serum calcium and serum phosphorus. During the pre-medication periods on the high calcium intake the serum calcium was $6.5 \mathrm{mgm}$. per $100 \mathrm{cc}$. and the serum phosphorus was $5.08 \mathrm{mgm}$. per $100 \mathrm{cc}$. These serum values remained unchanged during the first day of irradiated ergosterol administration. On the eighth day of this therapy, period 54, the serum calcium was $9.04 \mathrm{mgm}$. per $100 \mathrm{cc}$. and the serum phosphorus was $4.32 \mathrm{mgm}$. per $100 \mathrm{cc}$. It was during this period that the urinary calcium rose, but the fecal calcium fell to such a degree that a marked 


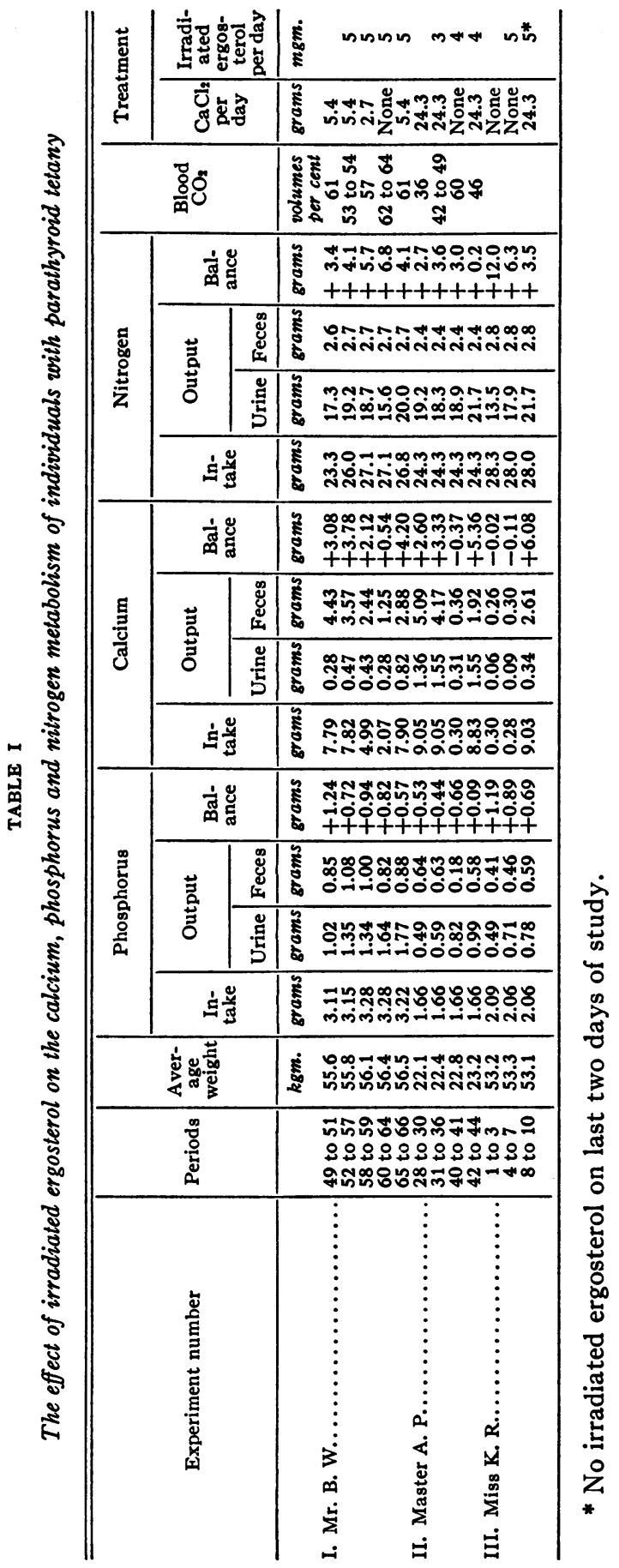


increase in the positive calcium balance occurred. When one compares the phosphorus metabolism in this period with that of the averages for the control periods, he finds that the fecal phosphorus was lower and the urinary phosphorus higher. During period 56, the fifteenth day of therapy, the serum calcium was $11.0 \mathrm{mgm}$. and the serum phosphorus was $3.69 \mathrm{mgm}$. The calcium and phosphorus metabolism changes were practically the same during periods 55 and 56 as they were in period 54 . When calcium chloride was omitted, period 60 , the serum calcium fell to $9.0 \mathrm{mgm}$. and the positive calcium balance was greatly reduced. The serum phosphorus rose to $4.6 \mathrm{mgm}$. and the positive phosphorus balance was slightly increased. On resuming calcium chloride therapy, the serum calcium rose to $10.0 \mathrm{mgm}$. and the positive calcium balance was greatly increased, whereas the serum phosphorus fell and the positive phosphorus balance was again decreased.

\section{Experiment II}

Master A. P., an 8-year old schoolboy, was known to have had idiopathic parathyroid tetany since the age of 4 . His dietary calcium intake was kept constant throughout the experiment, but was inadequate, 0.30 gram per three-day period. His data are presented in Charts $2 A, 2 B$ and Table I.

His total calcium intake during the control periods was brought up to an average of 9.05 grams per period by administering calcium chloride. The data obtained during the period of irradiated ergosterol medication were similar to those described in experiment I. (See Table I, periods 31-36.) Following the discontinuance of calcium chloride medication the calcium balance became negative and the positive phosphorus balance was slightly increased. The resumption of calcium chloride administration resulted in a positive calcium balance, much greater than that observed during comparable periods earlier in the experiment (periods 31-36).

The changes in the phosphorus metabolism were similar to those observed in the previous experiment.

In this experiment the changes in the serum calcium and phosphorus were very marked. During the control periods values of 8.0 and $7.8 \mathrm{mgm}$. were obtained for the serum calcium and 6.25 and $7.41 \mathrm{mgm}$. for the serum phosphorus. On the third day of ergosterol therapy, the serum calcium had risen to $10.0 \mathrm{mgm}$. and the serum phosphorus had fallen to $7.14 \mathrm{mgm}$. With the discontinuance of calcium chloride during periods 40,41 , and 42 , the serum calcium dropped to $5.6 \mathrm{mgm}$. and the serum phosphorus rose to $9.2 \mathrm{mgm}$. On resumption of calcium chloride therapy, the serum calcium rose abruptly to $10.0 \mathrm{mgm}$. and the serum phosphorus fell to $6.35 \mathrm{mgm}$. These values were maintained throughout the remainder of the experiment. 


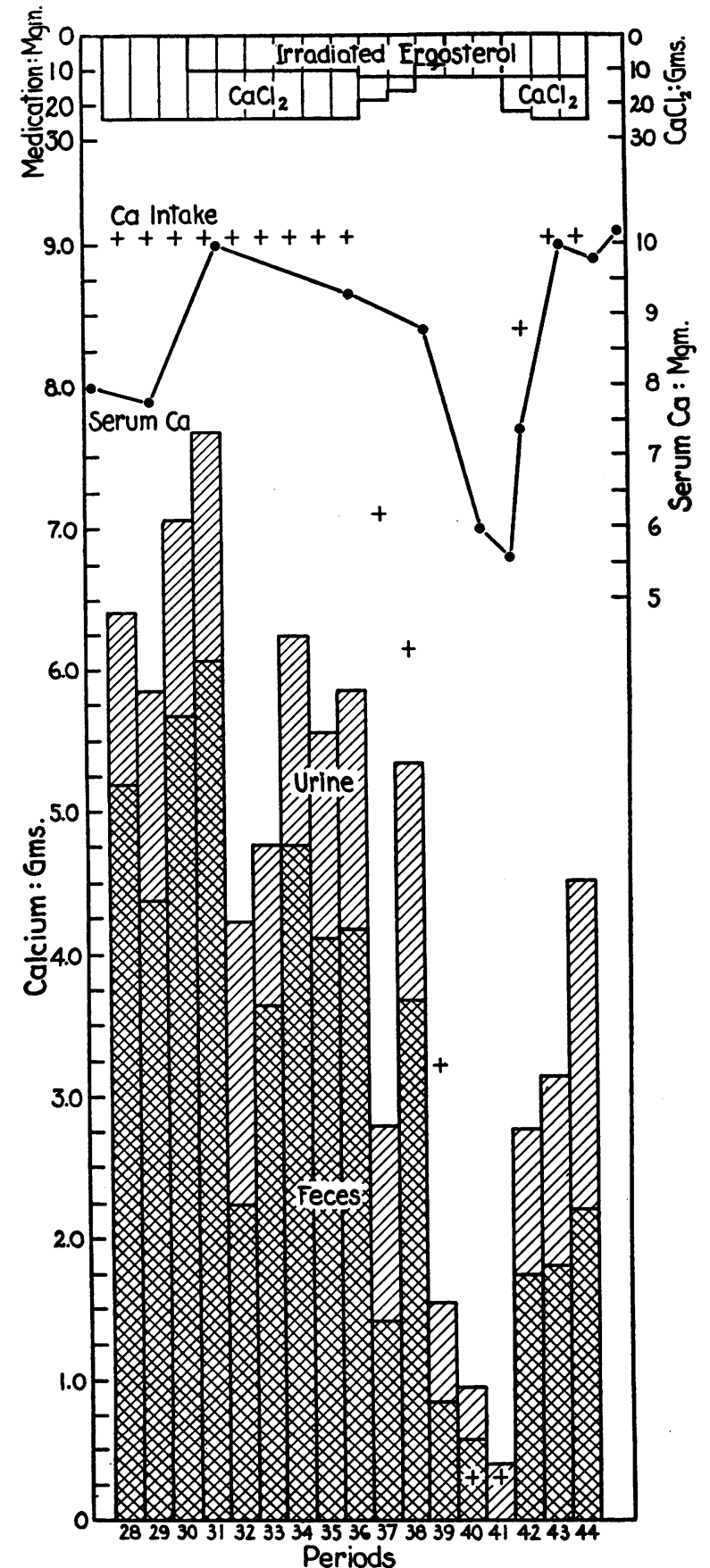

Chart 2A. Calcium Metabolism in Experiment II 


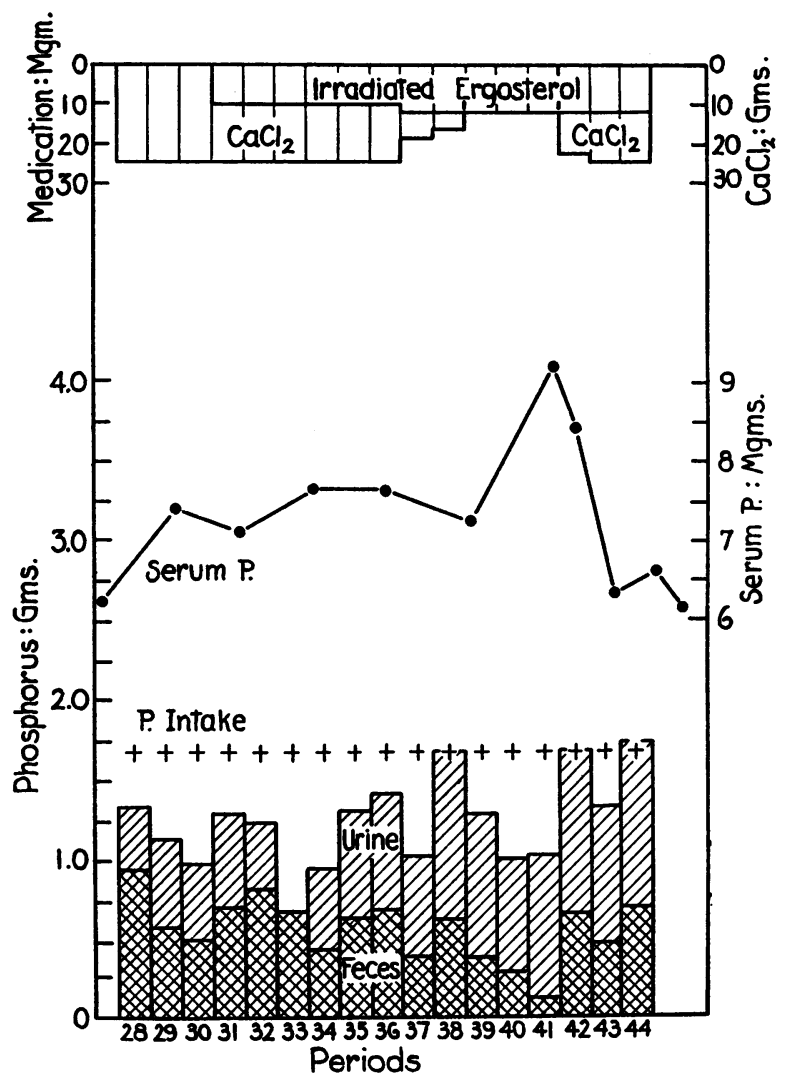

Chart 2B. Phosphorus Metabolism in Experiment II

\section{Experiment III}

Miss K. R., a 26-year old school health worker, entered the hospital first on December 19, 1928. Subtotal thyroidectomy was done on December 31, 1928. Because of the persistence of symptoms of thyrotoxicosis a second operation was done on May 23, 1929, when more thyroid tissue was removed. Three days later, carpopedal spasms were noted. The serum calcium was found to be $6.8 \mathrm{mgm}$. per $100 \mathrm{cc}$. and the serum phosphorus $4.6 \mathrm{mgm}$. per $100 \mathrm{cc}$. She was transferred to the Metabolism Ward for study and was placed on a low calcium diet ( 0.30 gram per three-day period). On June 13 , the serum calcium had fallen to 5.2 $\mathrm{mgm}$. and the serum phosphorus had risen to $6.7 \mathrm{mgm}$. It is noteworthy that in the progression toward abnormal blood values the calcium was found low at the time when carpopedal spasms were first noted, whereas the phosphorus rose gradually to its high level some eleven days later. Charts $3 A, 3 B$ and Table I contain the calcium and phosphorus metabolism data from this patient. 
From Table I one notes that the administration of irradiated ergosterol caused only slight changes in the calcium metabolism while this subject was on an inadequate calcium intake. The changes were so slight that one hesitates to ascribe them to irradiated ergosterol therapy.

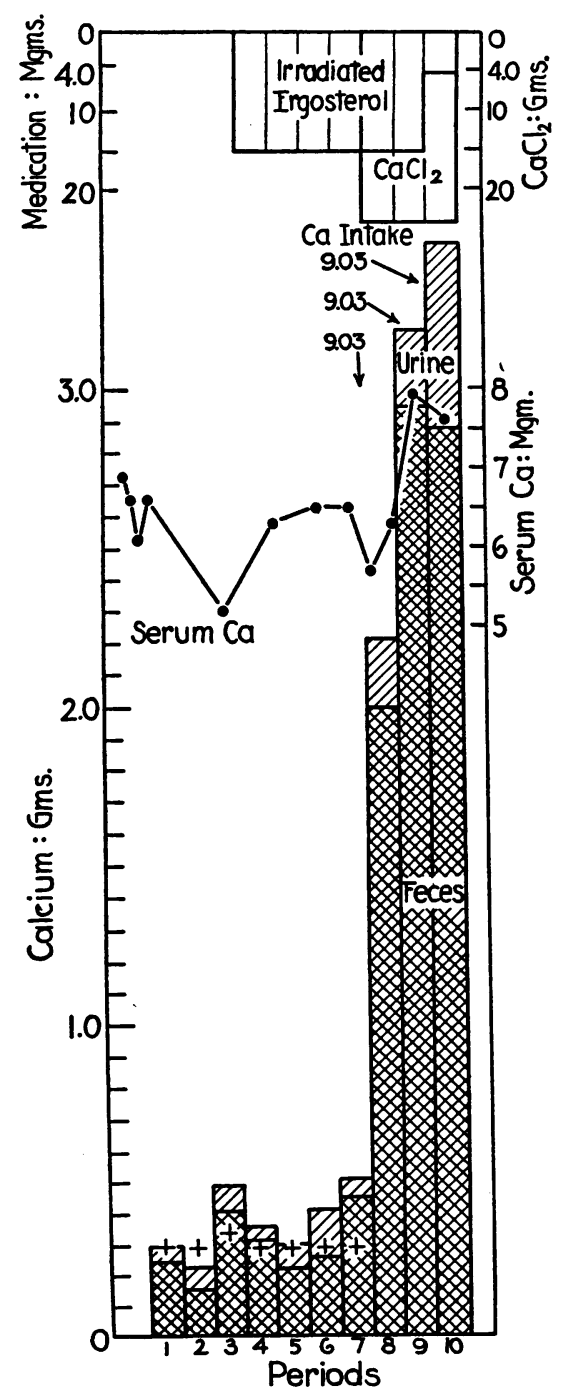

Chart 3A. Calcium Metabolism in Experiment III

The urinary phosphorus rose, the fecal phosphorus remained practically unchanged, and the positive phosphorus balance decreased. During the last three periods of this study, the calcium intake was increased to 9.03 grams per period by the administration of calcium chloride. Irradiated 
ergosterol therapy was continued during these three periods. A larger positive calcium balance ensued and the positive phosphorus balance decreased.

During the control periods the serum calcium varied between 5.2 and $6.6 \mathrm{mgm}$.; the serum phosphorus rose from 5.44 to $6.72 \mathrm{mgm}$. During the administration of irradiated ergosterol the serum calcium remained almost constant, 6.3 to $6.5 \mathrm{mgm}$.; the serum phosphorus gradually rose from

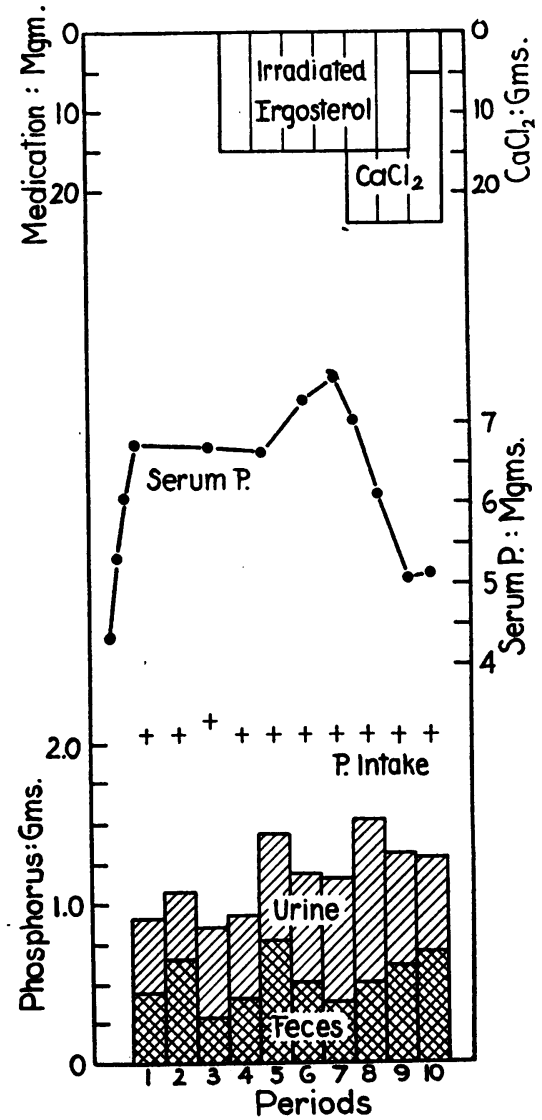

Chart $3 B$. Phosphorus Metabolism in Experiment III

6.7 to $7.6 \mathrm{mgm}$. per $100 \mathrm{cc}$. When calcium chloride was administered in addition to the irradiated ergosterol, the serum calcium rose to $7.9 \mathrm{mgm}$. (seventh day of therapy) and the serum phosphorus fell to $5.1 \mathrm{mgm}$. As our supply of irradiated ergosterol gave out on this day, none was administered during the last two days of period 10. This fact would seem to be an adequate reason for not having established normal serum calcium and phosphorus values in this case. 


\section{DISCUSSION}

From these experiments it is apparent that the beneficial action of irradiated ergosterol therapy on patients with parathyroid deficiency is dependent upon the calcium intake. The administration of $5 \mathrm{mgm}$. of irradiated ergosterol per day in experiment III was without effect on the serum calcium or phosphorus or the calcium and phosphorus metabolism when the calcium intake was inadequate ( 0.30 gram per three-day period). When the calcium intake was increased to 9.03 grams per period, there resulted a marked retention of calcium and a rise in the serum calcium, an increased phosphorus excretion and a fall in the serum phosphorus. Failure to obtain a greater elevation in the serum calcium was very likely due to the fact that the irradiated ergosterol was administered for only seven days.

In experiment II, the calcium intake was high (9.05 grams per period) during the pre-medication periods, yet the serum calcium and phosphorus values were characteristic of those found in parathyroid tetany. When irradiated ergosterol was administered the positive calcium balance increased and the serum calcium rose, whereas the phosphorus excretion increased and the serum phosphorus fell. Reduction of the high calcium intake to an inadequate one by discontinuing the calcium chloride therapy caused the calcium balance to become negative, the serum calcium to fall, the phosphorus excretion to decrease, the serum phosphorus to rise, and as a consequence the signs and symptoms of tetany returned. With the resumption of the calcium chloride there occurred the following changes: a marked positive calcium balance, a rise in the serum calcium, an increased phosphorus excretion and a fall in the serum phosphorus.

The results of experiment I were similar to those of experiment II, except that with the discontinuance of the calcium chloride there was no return of the signs and symptoms of tetany and the drop in serum calcium and rise in serum phosphorus were not so marked. These differences can be accounted for by the fact that the dietary calcium intake in experiment I was adequate whereas in experiment II it was inadequate.

These observations on patients with parathyroid tetany show that if the calcium intake is inadequate the administration of irradiated ergosterol is without effect, yet its administration in the same dosage when the calcium intake is high results in complete symptomatic relief and changes in the calcium and phosphorus metabolism corresponding to those reported in Studies I and II (11-12). When irradiated ergosterol was administered to patients receiving a high calcium diet, the following changes occurred: a moderate decrease in the fecal calcium, a rise in the serum calcium, a slight rise in the urinary calcium, and a consequent increase in the positive calcium balance. However, the phosphorus excretion was increased and the serum phosphorus fell. 
If the changes in the calcium and phosphorus metabolism observed in these patients are interpreted as being secondary to increased calcium absorption from the gastro-intestinal tract, they can be readily explained on the basis of the classification of disorders of calcium and phosphorus metabolism given by Albright, Bauer, Cockrill and Ellsworth (14). According to this classification, disorders of the parathyroid glands represent conditions in which the body fluids contain the saturating amount of calcium phosphate, but the proportion of the calcium ion to the phosphate ion is abnormal. In parathyroid tetany the calcium ion is reduced and the phosphate ion is increased. Because the body fluids already contain a saturating amount of calcium phosphate, the rise in the serum calcium (due to the increased absorption of calcium from the gastro-intestinal tract) is accompanied by a fall in the serum phosphorus and an increased phosphorus excretion in an attempt to keep the $\mathrm{Ca} \times \mathrm{P}$ product normal. However, the fall in the serum phosphorus is not sufficiently rapid and therefore the $\mathrm{Ca} \times \mathrm{P}$ product rises.

Further evidence to substantiate the belief that the beneficial action of irradiated ergosterol in parathyroid tetany is directly related to the calcium intake and is not secondary to the stimulation of any remaining parathyroid tissue is obtained when one compares the changes in the calcium and phosphorus metabolism of a normal individual while receiving an inadequate calcium intake plus an active parathyroid extract and when he is on the same diet but receiving irradiated ergosterol instead of parathormone. ${ }^{5}$

With the administration of an active parathyroid extract to a normal individual on an inadequate calcium intake there occurs (15):

1. An increased urinary phosphorus excretion;

2. A fall in the serum phosphorus;

3. A rise in the serum calcium;

4. An increased urinary calcium excretion;

5. No effect on the fecal calcium or phosphorus excretion;

whereas the administration of irradiated ergosterol in adequate doses to a normal individual on a low calcium diet causes:

1. A decrease in the fecal calcium;

2. A rise in the urinary calcium;

3. A decrease in the fecal phosphorus;

4. A rise in the urinary phosphorus;

5. Only slight elevation of serum calcium;

6. Little, if any, elevation of serum phosphorus.

Thus, the action of the two agents which are of most importance in the regulation of normal calcium phosphate metabolism is exactly op-

5 The trade name for the active principle of the parathyroid glands as prepared by the Eli Lilly Company. 
posite; the active principle of the parathyroid glands mobilizing calcium and phosphorus from the bones, vitamin $\mathrm{D}$ increasing absorption of these elements from the gastro-intestinal tract.

All the data presented in this series of papers strengthen the theory which has long been held by certain workers (16-27). Various workers have reported a shift in the $\mathrm{pH}$ of the stools from alkaline to acid when individuals with rickets are receiving vitamin $D$. An increased acidity of the gastro-intestinal tract would favor more complete absorption of calcium and phosphorus (28-29), yet analysis of the gastric and pancreatic juices has failed to reveal any increase in acidity during irradiated ergosterol therapy (35). Therefore, we are left with no explanation of the increased absorption of calcium and phosphorus from the gastrointestinal tract or of the reason for the observed shift in the $\mathrm{pH}$ of the stools. The increased acidity of the stools in rickets may be secondary to other changes such as (1) the secretion of a more acid succus entericus or (2) alteration of the permeability of the intestinal wall, thereby allowing more complete absorption of calcium and other basic ions. Further study is necessary to prove either of these last two mentioned modes of action.

Overdosage of irradiated ergosterol results in mobilization of calcium phosphate from the bones and decalcification (30). Because of this mobilization of calcium phosphate, the body fluids contain more than the normal amount of calcium phosphate, and calcium phosphate deposition takes place in tissues other than bones. This metastatic calcification is found more commonly in tissues where the carbon dioxide tension is more likely to be low (31). Why therapeutic doses of irradiated ergosterol result in an increased absorption of calcium and phosphorus from the gastro-intestinal tract and overdosage in mobilization of calcium phosphate from the bones cannot be answered accurately at this time, but there is an increasing amount of evidence which suggests that the toxic effects from excessive irradiated ergosterol dosage are due to contained impurities rather than to the vitamin D concentrate itself (32-34).

From these experiments as well as from those previously published it is apparent that small doses of irradiated ergosterol produce beneficial effects on patients with disorders of calcium and phosphorus metabolism, but the same doses are without effect on the calcium and phosphorus metabolism of normal individuals. These results further demonstrate that the dose required for adults is larger than that usually prescribed for infants and children. Therefore, it would be well to have this potent vitamin $\mathrm{D}$ concentrate prepared in two different strengths, one for children and one for adults. It must be remembered that the preparation used in these studies contained $10 \mathrm{mgm}$. in each cc. and that .0001 to $.00025 \mathrm{mgm}$. was sufficient to protect against rickets in rats fed on the Steenbock diet. 


\section{SUMMARY}

1. The beneficial results obtained in the treatment of parathyroid tetany when therapeutic doses of irradiated ergosterol are employed are directly related to the calcium intake and are not secondary to the stimulation of remaining parathyroid tissue.

2. The administration of $5 \mathrm{mgm}$. of irradiated ergosterol a day to an individual with parathyroid tetany on an inadequate calcium intake is without beneficial effects.

3. The administration of $5 \mathrm{mgm}$. of irradiated ergosterol a day to an individual with parathyroid tetany receiving a high calcium intake produces the following changes:

a. A decreased fecal calcium excretion;

$b$. An increased urinary calcium excretion;

c. An increased positive calcium balance;

d. A rise in the serum calcium;

e. An increased fecal phosphorus excretion;

$f$. An increased urinary phosphorus excretion;

$g$. A decrease in the positive phosphorus balance;

$h$. A fall in the serum phosphorus;

$i$. The serum calcium rises faster than the serum phosphorus falls and therefore the $\mathrm{Ca} \times \mathrm{P}$ product rises;

$j$. The signs and symptoms of tetany disappear.

4. The dose of irradiated ergosterol required to produce beneficial changes in the calcium and phosphorus metabolism of individuals with calcium and phosphorus disorders is smaller than the amount necessary to produce similar changes in the calcium and phosphorus metabolism of normal individuals.

\section{BIBLIOGRAPHY}

1. Hess, A. F., and Lewis, J. M., J. Am. Med. Assoc., 1928, xci, 783. Clinical Experience with Irradiated Ergosterol.

2. Hess, A. F., Weinstock, M., and Rivkin, H., Proc. Soc. Exp. Biol. and Med., 1929, xxvi, 555. Effect of Thyroparathyroidectomy on the Action of Irradiated Ergosterol.

3. Greenwald, I., and Gross, J., J. Biol. Chem., 1929, lxxxii, 505. The Prevention of the Tetany of Parathyroidectomized Dogs. I. Cod Liver Oil, with a Note on the Effect of Cod Liver Oil on Calcium Assimilation.

4. Brougher, J. C., Am. J. Physiol., 1928, 1xxxvi, 538. The Value of Acterol (Irradiated Ergosterol) in the Treatment of Thyroparathyroidectomized Dogs.

5. Gleich, M., and Goodman, S., New York State J. Med., 1928, xxviii, 1398. Irradiated Ergosterol in the Treatment of Tetany.

6. Stern, A., Deutsche med. Wchnschr., 1928, liv, 1292. Zur Therapie der parathyreopriven Tetanie mit Vigantol.

7. Brougher, J. C., J. Am. Med. Assoc., 1930, xciv, 471. Viosterol (Irradiated Ergosterol) in Treatment of Parathyroid Tetany. 
8. Jones, J. H., Rapoport, M., and Hodes, H. L., J. Biol. Chem., 1930, lxxxvi, 267. The Effect of Irradiated Ergosterol on Thyroparathyroidectomized Dogs.

9. Wade, P. A., Am. J. Med. Sci., 1929, clxxvii, 790. Clinical and Experimental Studies on Calcium and Cholesterol in Relation to the Thyroid Parathyroid Apparatus.

10. Urechia, C. I., and Popoviciu, G., Compt. rend. Soc. de biol., 1928, xcviii, 405. L'Ergostérine Irradiée dans la Tétanie Expérimentale.

11. Bauer, W., Marble, A., and Claflin, D., J. Clin. Invest., 1932, xi, 1. Studies on the Mode of Action of Irradiated Ergosterol. I. Its Effect on the Calcium, Phosphorus and Nitrogen Metabolism of Normal Individuals.

12. Bauer, W., and Marble, A., J. Clin. Invest., 1932, xi, 21. Studies on the Mode of Action of Irradiated Ergosterol. II. Its Effect on the Calcium and Phosphorus Metabolism of Individuals with Calcium Deficiency Diseases.

13. Bauer, W., and Marble, A., J. Clin. Invest., 1932, xi, 37. Studies on the Mode of Action of Irradiated Ergosterol. III. The Effect of Irradiated Ergosterol Administration on the Formation of Bone Trabeculae.

14. Albright, F., Bauer, W., Cockrill, J. R., and Ellsworth, R., J. Clin. Invest., 1931, ix, 659. Studies on the Physiology of the Parathyroid Glands. II. The Relation of the Serum Calcium to the Serum Phosphorus at Different Levels of Parathyroid Activity.

15. Albright, F., Bauer, W., Ropes, M., and Aub, J. C., J. Clin. Invest., 1929, vii, 139. Studies of Calcium and Phosphorus Metabolism. IV. The Effect of the Parathyroid Hormone.

16. Birk, W., Monatschr. f. Kinderh., 1908, vii, 450. Untersuchungen über den Einfluss des Phosphorlebertrans auf den Mineralstoff wechsel gesunder und rachitischer Säuglinge.

17. Birk, W., and Orgler, A., Monatschr. f. Kinderh., 1910, ix, 544. Der Kalkstoff wechsel bei Rachitis.

18. Hamilton, B., Acta Paediat., 1922, ii, 1. The Calcium and Phosphorus Metabolism of Prematurely Born Infants.

19. Klotz, M., Handbuch der Inneren Medizin, 1926, iv, 524. Rachitis.

20. Freise, E., and Rupprecht, P., Monatschr. f. Kinderh., 1920, xix, 115. Untersuchungen über den Einfluss der Vegetabilienzufuhr auf den Kalk- und Phosphorstoff wechsel des gesunden und des rachitischen Kindes.

21. Muhl, G., Acta Paediat., 1925, v, 188. The Fat Absorption and the Calcium Metabolism of Prematurely Born Infants.

22. Cronheim, W., and Müller, E., Biochem. Ztschr., 1908, ix, 76. Stoffwechselversuche an gesunden und rachitischen Kindern mit besonderer Berücksichtigung des Mineralstoff wechsels.

23. Orgler, A., Monatschr. f. Kinderh., 1911, x, 373. Über den Kalkstoffwechsel bei Rachitis.

24. Rominger, E., and Meyer, H., Monatschr. f. Kinderh., 1926, xxxiv, 408. Langfristige ununterbrochene Mineralstoff wechseluntersuchungen an Säuglingen, ihre Methodik und bisherigen Ergebnisse.

25. Schlossman, A., Arch. f. Kinderh., 1904, xl, 1. Ueber Menge, Art und Bedeutung des Phosphors in der Milch und über einige Schicksale desselben im Säuglingsorganismus. 
26. Schloss, E., Jahrb. f. Kinderh., 1913, lxxviii, 694. Zur Therapie der Rachitis. I. Die Wirkung von Phosphorlebertran und Calcium aceticum auf den Stoff wechsel des natürlich ernährten rachitischen Kindes. Ibid., 1914, lxxix, 194. Zur Therapie der Rachitis. III. Die Wirkung von organischen und anorganischen Kalkphosphorpräparaten auf den Stoff wechsel des natürlich ernährten rachitischen Kindes.

Ibid., 1915, lxxxii, 435. Zur Therapie der Rachitis. VIII. Zusammenfassung der Versuche.

Ibid., 1916, lxxxiii, 46. Zur Therapie der Rachitis. VIII. Zusammenfassung der Versuche. B. Die Versuche bei kalkphosphatarmer künstlicher Ernährung (Fettmilch).

27. Schabad, J. A., Ztschr. f. klin. Med., 1910, 1xix, 435. Phosphor, Lebertran, und Sesamöl in der Therapie der Rachitis; Ihr Einfluss auf den Kalk-, Phosphor-, Stickstoff-, und Fettstoffwechsel.

28. Irving, L., and Ferguson, J., Proc. Soc. Exp. Biol. and Med., 1925, xxii, 527. The Influence of Acidity in the Intestine upon the Absorption of Calcium Salts by the Blood.

29. Abrahamson, E. M., and Miller, E. G., Jr., Proc. Soc. Exp. Biol. and Med., 1925, xxii, 438. Hydrogen-ion Concentration in the Gastro-Intestinal Tract of the Albino Rat.

30. Shohl, A. T., Goldblatt, H., and Brown, H. B., J. Clin. Invest., 1930, viii, 505. The Pathological Effects upon Rats of Excess Irradiated Ergosterol.

31. Smith, M. I., and Elvove, E., Pub. Health Rep., 1929, xliv, 1245. The Action of Irradiated Ergosterol in the Rabbit.

32. Bamberger, P., Deutsche med. Wchnschr., 1929, lv, 399. Zur Frage der Vigantolschäden.

33. Von Wendt, G., Klin. Wchnschr., 1930, ix, 166 . Ist das D-Vitamin eine einheitliche Substanz?

34. Windaus, A., Forshungen und Fortschritte, 1930, vi, 209. Ergosterin und Vitamin D.

35. Bauer, W., Marble, A., Maddock, S. J., and Wood, J. C., Am. J. Med. Sci., 1931, clxxxi, 399. The Effect of Irradiated Ergosterol on the Composition of Gastric and Pancreatic Juices. 